\title{
Shaping Place Identity in Urban Villages with Community Mural
}

\author{
Ernest Irwandi ${ }^{1}$, Setiawan Sabana ${ }^{2}$, and Andryanto Rikrik Kusmara ${ }^{3}$ \\ 1,2,3 Institut Teknologi Bandung \\ ${ }^{1}$ ernest.irw@gmail.com,${ }^{2}$ setiawansabana@yahoo.com ${ }^{3}$ twinrik@gmail.com
}

\begin{abstract}
Globalization has caused rapid expansions of cities and increased mobility of culture. In Indonesia, traditional settlement that is used to coexist with nature must face the challenge of modernization. Expansion of modern cities squeezed traditional settlements between commercial complexes and cause formation of segregated settlements, known as urban villages. Poor urban development often causes gentrification, thus producing slum areas and creates social disparity. This paper discusses mural decorations in urban villages of Java Indonesia that have transformed slum areas into iconic places. Decorating urban villages with mural has become a movement across Java for almost a decade. Several urban villages have evolved to become tourist destinations and part of the city's identity. This research studies the production of place identity through community murals. A Combination of methods will be used in this research. First visual ethnography is used to examine local culture in one urban village of Java Indonesia. Second participatory approach will be used to examine the production process of community mural and to analyze how art can empower a community.
\end{abstract}

Keywords: Place Identity, Community Mural, Urban Villages, Local Culture, Participatory.

\section{INTRODUCTION}

Environment shapes society and can gradually shape a distinct culture. In the past, natural environment shape identity of places and cultures. For example: coconut trees had influenced traditional Balinese coastal culture extensively, from crafting utensils to constructing houses. In traditional Balinese culture, people that lived closer to the mountain had a different environment, banana trees are the common plant used in everyday life. Environment shape a culture further, into complex relationship of communities thus every place produce distinct material culture. The simplest way to understand place identity is to examine the people's environmental preference, everyday activities, occupation and local knowledge [1]. Identity of a place cannot be simply observed in contemporary standpoint, because every social and cultural action carries something from the past, either consciously or unconsciously. Take recipe as example that began with our ancestor's inspiration to formulate, in a particular place where certain ingredients were abundant. The cooking style and the eating manner that are entangled in place and memory in particular phase of life had been passed across generations. In summary the contemporary is parcel of past time [2]. Identities are not in a fixed state as they are in constant mutation as long as material culture constantly produced and changed across time and space. The physical settings of the environment and the history of a place, 
depend on the people's attitude and respond to the two factors. To understand the people's attitude it is necessary to examine the cultural history in relation to the physical setting. Specificity of a place is not constructed only by long internalized history, but also by a constellation of social relations, that meets and interweaves in particular locus. In the globalized world, with the increasing mobility of culture, each place is a unique meeting place constructed by a particular global intersection, the area without strict boundaries [3]. The increased mobility of culture also intensifies local imaginaries thus changing the perspective on place identity and heritage. Place identity and heritage is not necessarily looked upon only as monolithic culture that was shaped at a particular period of time, but also sculpted by time and immersed in multiple dimensions. The narrative of a place is shaped by advancement of technology, globalization and community actions. This paper discusses how art, specifically mural art, plays an important role in midst of contemporary urban conditions.

\section{METHOD}

This research lies in the domain of visual culture, aiming to study and explore the process in narrating communal memories and local values through visual representation, by engaging in community mural project. This research is an in depth study, conducted with combination of interviews, participant observation and focused group discussions. Participatory action research and visual ethnography will be used in several stages. Visual ethnography will be used as a part of the research design to investigate local content in a particular place, specifically to examine: how local content still play a role in communities today, and how it is re-contextualize or represent in current condition?

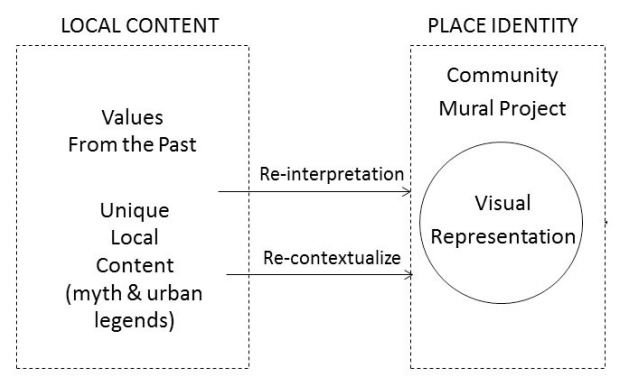

Fig.1. visual representation process in shaping place identity

Participatory approach will be used in art experiment as a tool to analyze various creative collaborative models for community mural projects, which involve participation of communities and stakeholders. As reference for this research design, participatory action research will be the main model. Series of programs such as workshops and art projects will be integrated within the participatory action research model.

According to McTaggart, Participatory Action Research (PAR) was developed as a means to improve and inform social, economic and cultural practices [4]. In principle, PAR is a group of activities in which individuals with certain strengths, status or someone who has different influences, collaborate into a context. The action research consists of four stages in each cycle of iteration: Plan, Action, Observe and Reflect. 'Plan' is the early stage to identify problems of the research, followed by 'Act' which is the implementation of the action research. 'Observe' is where researcher conducts a thorough observation of all the activities and process during the 
research. 'Reflect' is to examine the effect of the action, evaluate and write recommendation. The iteration cycle continue and stops after satisfactory results are achieved [5].

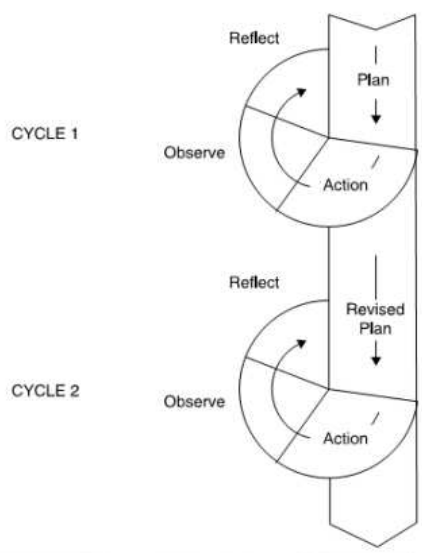

Fig.3. Kemmis and McTaggart Action Research model Source: Burns 2010

To examine level of participation, Arnstein's ladder is still an important concept for researchers as a guide to understand which stages of participation. Arnstein uses a ladder as analogy to explain participatory stages.

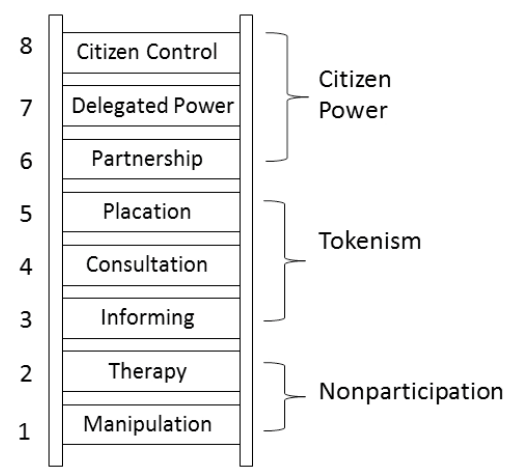

Fig. 2. Arnstein's Partisipatory Ladder 1969

Source: Kindon, Pain and Kesby 2007

On the first and second rung of the ladder 'Manipulation' and 'Therapy', Arnstein explained that at this stage participation was at the lowest position, when powerholders or facilitators educate to change the attitudes of citizens in order to get public support. The third rung is 'Informing', the level of participation is increasing although it is still low. At this stage the facilitator provides one-way information. Information is conveyed to residents but citizens are not given the opportunity to contribute for decision. On the fourth rung is 'Consultation', where the powerholders or facilitator gives advice or direction to the residents. Residents are given the opportunity to give their views. Although the views of citizens are heard and obtained through various means, residents are not involved in decision making. On the fifth 
rung is 'Placation' the placement of citizens into decision making process. Citizens are given the opportunity to play an active role in forming opinions and ideas but the final decision remains with the facilitator or the powerholders. On the sixth rung is 'Partnership', at this level two way communication between powerholders and citizens is key factor and citizen involvement in decision making is encouraged. The seventh rung is 'Delegated Power', where power is delegated to citizens to make decisions. The facilitator establishes joint decisions and citizens have the authority to ensure accountability. On the eighth rung is 'Citizen Control', where residents have full control in handling all planning, making policies, and managing programs. Iteration stages and levels of participation will underlie this research design to examine how residents' participate in decisions making process and evaluate implementation at each stage of Participatory Action Research [6].

\section{RESULT AND DISCUSSIONS}

In the globalized world, cities rise and continue to expand. The rapid expansion of cities causes problems of social disparity and this occurs throughout the world with a variety of underlying factors. Expansion of cities bring exciting new things but also baggage of problems, most of the population today lived in urban area and quality of urban life always need constant attention. According to Guy Debord, modern urban life that is driven by capitalism diminishes dimensions of life into a model that is reduced in just two patterns, work and consumption and Debord seeks to explore new meanings in everyday urban life [7]. While Debord sees spectacle as alienating, Bourriaud saw the art as tool in creating and reviving relational spaces in social life and proposes the concept of 'relational aesthetics'; as art sees human interaction and social context as source of inspiration. Art relate in society by perceiving, commenting, creating a dialogue and evolving in space and time. Bourriaud sees artistic activity as a game which the form, pattern and functions always develop, evolve through time; it relate to social context and it is constantly mutable [8].

In the process of dialogue, art is a symbolic work exchanged in society. Symbolic work in community produce, reproduce and strengthened collective identity. The process of symbolic work includes the struggle to create meaning through the experiences of individuals in a community in reaching a point of realization about their collective structure and their differences; the process is inter-subjective. Community elements are not just simply produce but lived and experienced in variety of responses. Symbolic creativity shaped collective structure by shaping material context of a culture. It speaks of capacity and experience of one community and the imagined ideals within any group.

\subsection{Mural art as a response to urban condition}

Murals in the city tell various underlying social and cultural issues. Most of mural movement expresses environmental, cultural, marginalization issues and other various concerns about neighborhood. Since 1960 the mural has changed the character of the public spaces of major cities around the world. The mural fills the corners of the city with themes that celebrate cultural diversity or various political views. Murals in the United States during 1960s mostly inspired by Civil Rights movement and speak about the equality of rights of African American and Latin American descent. From 1950s to late 1960s mural themes in the United States, especially in New York, San Francisco, Chicago and California, were combination of cultural traditions, myths and local community expressions. These murals are created by communities and later become art movements that represent community values, 
concerns for injustice, reject racism and express collective identity [9]. This community-based mural movement is a social movement in urban areas that encourages diaspora communities to trace back to their cultural roots in an effort to find bonds with their ancient ancestors [10].

\subsection{Shaping place identity in urban villages of java}

Mural movement have change urban landscapes in many part of the world. In the corner of cities, murals drive community actions, establish community dialogue, help in enriching local perspective by various means that mural messages can deliver, whether it is provocative persuasive or expressive. During late 1930s to 1945 in Indonesia pre-independence era, mural movement in urban area are provocative calling to all young generation in Indonesia to take part in the struggle for independence. Since 1980s until today most murals in Indonesia consist of critics to the government, speaks of injustice, political contestation, cultural and artistic expressions [11].

For almost a decade after entering the millennium, decorating urban villages with mural have become movements across Java, Indonesia. Several urban villages have evolved to be tourist destinations. The villages decorated with murals have similar characters most of the villages are located in the middle of the city or known as 'Kampung Kota' or urban villages. The existence of urban villages in cities across Java Island can be traced from Indonesian post-independence era when Indonesia entered early stage of city development. Since 1980s most of the regions in Java have experienced regional expansion as a result of expanding economic activities. In the past, most settlements were surrounded with rice fields and forest, gradually developing into a city. The villages which has long existed, is now surrounded by modern buildings. In contrast with modern housing and buildings, several urban villages have minimal access to public facilities such as: clean water, security or waste management and residents have to strive for solution by themselves.

Urban villages is often known as a slum area, but several urban villages on the island of Java have succeeded in transforming slum area into creative spaces and become tourist destinations, among others are: Jodipan Village in Malang, Pelangi Village in Semarang, Village Bulak Kenjeran in Surabaya, Kampung Bekelir in Babakan Tangerang, colorful villages in Katulampa Bogor and Kampung Cibunut in Bandung. Creating murals in these villages are not entirely independent effort by residents in the urban villages, because mural projects require thorough planning involving many stakeholders. This mural movement exhibits process of art creation that has a social impact. Creative communities from various regions collaborate and in the process these mural project create bonding experience between individuals and communities, mural bridges personal and communal aspirations. The presence of urban villages decorated with murals also added value to the city and became an inseparable part of the city's identity.

Most visitors don't stop only for the attractive colors of the village but also for the uniqueness of each village. The village in river banks of Code in Yogyakarta is known for the story of Mangunwijaya an architect who helped building the Code village. To this day his services is still remembered and his face is portrayed in a mural in one of the walls in Code village. Jodipan village in Malang is known for its three-dimensional thematic paintings that are always updated by the artists' community. Bulak Kenjeran village in Surabaya is known for the uniqueness of local fishermen community. The colorful villages in Katulampa, Bogor are known for its water attractions. The mural in Kampung Bekelir in Babakan Kota Tangerang has an educational theme. Cibunut village in the city of Bandung is known for its 
thematic murals about cultural and educational themes. In Kampung Pelangi Semarang the beauty lies in the topography of the village which is located on a hill.

\subsection{Participatory Action Research in Community Mural Project}

This research is still in progress. It started at 2018 in Kampung Wonosari, Randusari Semarang City, or currently known as Kampung Pelangi or Rainbow Village, and still on going at the time of writing. Kampung Pelangi was chosen as the research locus based on several key factors. Kampung Pelangi is part of the 'Thematic Village Program' one of government development program aim to improve the quality of the environment by taking into account factors such as: improving environmental conditions, raising social and economic potential through empowerment programs, enhancing cultural character, local wisdom, and enhancing local characteristics as icon of the region. Although the colors of Kampung Pelangi have succeeded in becoming the new identity of the City of Semarang, other creative efforts are still needed to enrich the value, especially regarding exploration of local culture and its historical context. In this research participatory action research, will be the main approach. Arnstein's ladder concept will be used as guide to understand the level of participation of residents in community mural projects. Residents are placed in discussion groups. Each resident are given the opportunity to play an active role in expressing ideas. The key factor that will result a success of intervention is when residents begin to increase their degree of participation along the process. The later stage of the research is to further engage two-way communication with residents. Conducive atmosphere of discussions is the key factor that is require in the planning stage.

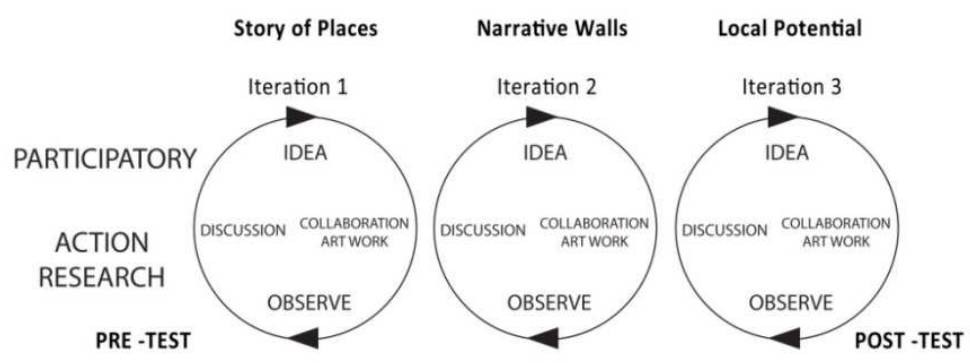

Fig.4. Participatory methods for art experiment process

Borrowing Kemmis and McTaggart iteration cycles, in this research the iteration process will be performed in three cycles. Each cycle of the iteration consists of four stages which involve ideation, collaboration, observation and group discussion [12]. The ideation stage aims to gain residents' perspective, collect ideas from residents and map ideas into categories. The stage will be followed by collaborative work, where in this stage residents are engaged in hands on art workshop to learn art skills to exchange and produce visual art works. The third stage of iteration is to summarize all the observation process which is performed simultaneously throughout the iteration stage, the observation process is performed by the research team which involves documentation and observation by cross referencing to research indicators checklist. The fourth and last stage is focus group discussion, in this stage all participants share their experiences and insights after being involved in all four stages. The iteration will be repeated in three cycles with similar pattern but each cycle designed for specific research 
target. The three cycles will be divided into three clusters. In this particular research, each cycle will be named specifically for the nature of this research scope. The first cluster is to explore 'Story of Places', the second cluster is to create 'Narrative Wall' and the third cluster is to enhance 'Local Potential'. The series of workshop carried out in iteration process will differ according to each of participatory research aims and the themes of each cluster will differ according to the uniqueness of the research locus.

\section{CONCLUSION}

Mural decoration movement that is happening in urban villages in Java is an interesting artistic phenomenon that calls many creative communities to engage and calls students to conduct research but most important it is a call to produce, to organize and to participate in a unique movement through process of shaping identities. It is a process that requires constant re-evaluating of ourselves to understand global challenges. For artistic research it is to examine how art can be a catalyst that sparks creative movement and what are the required models of research, functions of technology in the production of art, and by exploring place history, embracing and re-contextualizing local values. The use of PAR as research model integrated with community-based art projects will show the level of citizen participation and empowerment that can be increased in accordance with the appropriate indicators. In addition, PAR can also show multi-roles for artists and facilitators. This research hypothesis tries to prove not only as a visual initiator but as a catalyst that can ignite the creativity of citizens in a community.

\section{REFERENCES}

[1]. Gray, A. and McGuigan, J. "Studying Culture an Introductory Reader". London, Arnold, 1993.

[2]. During, S. "Cultural Studies a Critical Introduction”. New York, Routledge, 2005.

[3]. Massey, D. "A Global Sense of Place”. In Studying Culture an Introductory Reader. London, Arnold, 1993.

[4]. Kemmis, S dan McTaggart, R. The action research planner (3rd ed.). Geelong, Australia: Deakin University Press, 1988.

[5]. McTaggart, R. Action research: A short modern history. Geelong, Australia: Deakin University Press, 1991.

[6]. Arnstein, Sherry R.'A Ladder Of Citizen Participation', Journal of the American Planning Association, 35: 4, $216-224,1969$.

[7]. Debord, G. "Society of Spectacle”. Michigan: Black \& Red Publishing, 1970.

[8]. Bourriaud, N. "Relational Aesthetics". Translated by Simon Pleasance, Fronza Woods and Mathieu Copeland. Paris: Les presses du reel, 2002.

[9]. Barnett, A.W. “Community Murals: The People's Art”. Cranbury, NJ: Associated University Press, Inc., 1984.

[10]. Harris, M.D. “Urban Totems: The Communal Spirit of Black Murals in Walls of Heritage Walls of Pride African American Murals”. California: Pomegranate Communications, Inc. p.24, 2000.

[11]. Barry, S. “Jalan Seni Jalanan Yogyakarta”, Yogyakarta: Studium, 2008.

[12]. Kindon, S., Pain, R. and Kesby, M. Participatory Action Research Approaches and Methods: Connecting people, participation and place. London: Routledge, 2007.

[13]. Leavy, P. Research Design Quantitative, Qualitative, Mixed Methods, Arts Based, and Community Based Participatory Research Approaches. London: Guilford Press, 2017.

[14]. Bae, S.W. "Balancing Past and Present: Reevaluating Community Murals and Existing Practices", Philadelphia, University of Pennsylvania, 2016.

[15]. Tunnacliffe, C.M. "The Power of Urban Street in Re-Naturing Urban Imaginations and Experiences", London, The Bartllet, University College London, 2016. 